\title{
EGFR Mutant-specific Inhibitor ZN-e4
}

National Cancer Institute

\section{Source}

National Cancer Institute. EGFR Mutant-specific Inhibitor ZN-e4. NCI Thesaurus. Code C153173.

An orally available selective inhibitor of certain epidermal growth factor receptor (EGFR) activating mutations, including the resistance mutation T790M, with potential antineoplastic activity. Upon administration, the EGFR mutant-specific inhibitor ZN-e4 specifically binds to and inhibits selective EGFR mutations, which prevents EGFR mutantmediated signaling and leads to cell death in EGFR mutant-expressing tumor cells. Compared to other EGFR inhibitors, ZN-e4 may offer therapeutic benefits in tumors with T790M-mediated drug resistance and may limit toxicities associated with non-selective EGFR inhibitors. EGFR, a receptor tyrosine kinase mutated in many tumor cell types, plays a key role in tumor cell proliferation and tumor vascularization. 